\title{
EXCEPTIONS TO A GENERAL PROHIBITION ON HANDGUN POSSESSION: DO THEY SWALLOW UP THE RULE?
}

\author{
JAMES B. JACOBS*
}

\section{INTRODUCTION}

Current American gun law generally allows most people to own firearms, and there are approximately 140 million guns in private possession. It is estimated that one-third of the privately-owned firearms are handguns. ${ }^{1}$ Only members of the most unreliable social categories-drug addicts, the mentally ill, convicted felons, juveniles ${ }^{2}$-are denied permission to own firearms. ${ }^{3}$ Some who decry this situation advocate "total disarmament," arguing that everyone would be safer if no one were permitted to possess a firearm, especially a handgun. ${ }^{4}$ They believe that a universal right to own firearms,

Copyright $\odot 1986$ by Law and Contemporary Problems

* Professor of Law and Director, Center for Research in Crime and Justice, New York University.

I appreciate the comments at various stages in the preparation of this article of John Baldwin, William Geller, Michael McConville, Norval Morris, and Franklin Zimring. I am grateful for the opportunity to have tested some of the ideas contained in this article at a faculty research seminar at New York University School of Law, and have benefited from the advice of my colleagues Graham Hughes, Lewis Kornhauser, Steve Reiss, Larry Sager, and many others. I am also grateful for the excellent research assistance of Mary Jane Shimsky.

1. J. Wright, P. Rossi \& K. Daly, Under the Gun: Weapons, Crime, and Violence in AMERICA 41-42 (1983).

2. The assumptions behind these exclusions are a subject worth pursuing, although beyond the scope of this article. One might readily question, for example, what justifies a conclusive presumption that any convicted felon would be an unreliable gun owner.

3. See, e.g., 18 U.S.C. § 922(d), (g), (h) (1982); ALA. CODE § 13A-11-72, -76 (1982); ALASKA Stat. $\S \S 11.61$ (a), .210(a), .220(a)(3) (1984); Cal. Penal Code $\$ \S 1202,12021.5$ (West 1982); C.al. Welf. \& INST. Code $\$ \$ 8100,8103$ (West 1984); Mich. CoMp. LAWS ANn. $\$ 28.422$ (West 1981).

Whether states have an administrative system to enforce these restrictions is another matter. As of 1981, only 25 states and the District of Columbia imposed purchasing or licensing requirements. legislative Reference Bureau, State of Wisconsin, Gun Control: a look at the Various State and Federal Laws 5 (1981).

4. Many groups concerned about handgun violence advocate a comprehensive national law to ban the manufacture, sale, and private possession of handguns. "As long as Americans still keep handguns under the mattress, in the closet, and in the glove compartment, none of us is safe." National Coalition to Ban Handguns, Twenty Questions and Answers, at question 7 (1981) (pamphlet). "The most effective way to prevent the 10,000 annual deaths by handguns would be to outlaw the weapons entirely, or at least require that ownership be contingent upon proving need." Dayton (Ohio) Journal Herald, Sept. 12, 1981, at 18, reprimed in The SNubnosed Killers: Handeuns IN America 33, 33 (1981) (Cox Newspaper Series). "I believe that handguns should be only for law enforcement personnel and the military, period. A handgun is designed to kill people." New York Daily News, Feb. 18, 1981, reprinted in The Snubnosed Killers: Handguns in America 33.33 (1981) 
especially handguns, makes guns more accessible to criminals and more likely to be misused by law abiding citizens; thus, they advocate a program of prohibition.

Many gun control skeptics have pointed out the practical difficulties of disarming what might amount to one in four American households ${ }^{5}$ and suppressing a black market in new and used guns. It would be impossible to enforce handgun prohibition against a highly resistant public; therefore, a disarmament proposal would have to enjoy widespread support to have even a small chance of success. Without the cooperation of gun owners and wouldbe owners, gun prohibition would be no more successful than alcohol prohibition, perhaps less so. ${ }^{6}$ Reducing the stockpile of firearms in private hands depends upon changing public perceptions about the necessity and desirability of owning and carrying firearms. The thesis of this article is that gun control proposals that allow for large numbers of individuals and groups to retain their weapons will not encourage voluntary and cooperative disarmament by nonexempt individuals and groups. To the contrary, politically expedient gun control proposals, rife with exemptions, will be viewed cynically and hostilely. In fact, such proposals legitimate the value of gun possession for persons and groups with "good reasons" for possessing firearms. This article seeks to understand why gun control proposals categorically exempt any groups. Is there more than political expediency at work?

Most gun control proposals put forward in the last few years are not likely to be perceived as fair because they explicitly and implicitly recognize the value and importance of gun ownership by carving out gaping exceptions to a general gun prohibition. Close examination reveals that many prohibitionists are not advocating "total disarmament." To begin with, practically all "control" scenarios seek to prohibit only "handguns," leaving people free to own rifles, shotguns, and other long guns. Some scenarios would ban only "Saturday Night Specials," leaving people free to own more expensive and powerful handguns as well as long guns. Nor do handgun-only prohibitionists mean to eliminate all handgun ownership; exceptions are invariably made for persons judged to have good reasons for owning or carrying

(Cox Newspaper Series) (quoting Charles Moore, Assistant FBI Director in charge of the criminal investigative division).

5. See, e.g., Moore, The Bird in Hand, 2 J. Pol'y Anaiysis \& Mgmt. $185-95$ (1983).

6. For an informative account of the national prohibition, see J. Kobler, ArdfNT SPIRITS: The. Rise and Fall of National. Prohibition (1973).

7. It is no easy matter to define or identify a "Saturday Night Special." The term is not a term of art, but rather an ambiguous reference to cheap handguns:

"Saturday Night Special," a phrase coined in Detroit to describe inexpensive handguns used to commit murder, robberies, and other crimes during weekend outbursts of violence, has manv definitions. Some define it as a small handgun, others as an inexpensive handgun. and still others as an inexpensive and low quality handgun. with "low quality" often measured by the melting temperature of the firearm's metal parts. The most commonly accepted definition of the weapon seems to focus on its low cost and low quality, while the majority of proposals in Congress using the term focus on the combined factors of size. quality. and cost in that order of priority. 
handguns. Police, private security guards, private investigators, business persons, and selected individuals are typically exempted from handgun bans.

These categorical exceptions raise profound and politically volatile equity concerns. As more people fall within the exceptions, there is less moral force behind the prohibition; the exceptions reinforce the apparently widely held feeling that handguns are valuable, even necessary, for personal security. Even a small number of broad exceptions might discourage people from voluntarily discarding their handguns, or from cooperating with a prohibition law.

Analysis of the exceptions that survive handgun prohibition has several useful functions. First, it clarifies to what extent general "prohibition" with exceptions differs from free availability with exclusions. Second, it demonstrates how susceptible exceptions are to controversy and conflict. Third, it shows the difficulty of preventing exceptions from swallowing up a general prohibition. Fourth, it focuses attention on basic policy issues: Who should be allowed to possess or carry various sorts of firearms and why? Fifth, and most importantly, it invites consideration of the relationship between a police firearms policy and a general firearms policy. If the police showed leadership in disarming or "de-arming" themselves, more private citizens, including gun owners, might view firearms as unnecessary in their own lives.

Part II of this article examines two recent handgun control ordinances in order to identify exceptions to handgun prohibition in the context of actual legislation. Part III seeks to identify the justifications for recognizing any exceptions, and argues that only if these justifications are very limited could gun prohibition be perceived as morally coherent and politically conceivable.

\section{Recent Handgun Bans and Their Exceptions}

In 1981 and 1982, gun bans in San Francisco, California and Morton Grove, Illinois drew a good deal of national attention. These ordinances were hailed as victories in the battle to prohibit handguns. Yet close inspection reveals that neither of these ordinances is a "total prohibition"; both permit many people to keep a firearm at home or at work.

S. Brill, Firearm Abuse: A Research and Policy Report 48 n.6 (1977); see also Cook. The "Salluday Night Special": An Assessment of Alternative Definitions from a Policy Perspective, 72 J. Crim. L. \& Criminology 1735 (1981).

A Maryland court recently held in products liability litigation that manufacturers of "Saturda! Night Specials" could be held strictly liable for injuries resulting from such weapons" use. Kelley $:$

R.G. Industries, Inc., 497 A.2d 1143 (Md. 1985). In reaching this holding, the court noted:

There is no clear-cut, established definition of a Saturday Night Special, although there are various characteristics which are considered in placing a handgun into that category. Relevant factors include the gun's barrel length, concealability, cost, quality of materials, quality of manufacturer, accuracy, reliability, whether it has been banned from import by the Burcau of Alcohol, Tobacco and Firearms, and other related characteristics. . . Because many of thesc factors are relative, in a tort suit a handgun should rarely, if ever, be deemed a Saturday Night Special as a matter of law. Instead, it is a finding to be made by the trier of facts.

Id. at 1159-60. 


\section{A. The San Francisco Handgun Control Ordinance}

San Francisco's controversial Handgun Control Ordinance was a response to the assassination of the mayor and a city councilman. A California appellate court struck the ordinance down on statutory grounds before it was to go into effect. ${ }^{8}$ For present purposes, however, the ordinance provides a valuable example of the type of gun control thought socially desirable and politically achievable in contemporary American society and the kinds of exemptions that are likely to arise under legislation prohibiting handgun ownership.

The San Francisco ordinance begins as if it were a flat prohibition: "It shall be unlawful for any person to possess, within the City and County of San Francisco, any handgun."9 This tough language sounds like a total prohibition, but it leaves a vast amount of weapons possession undisturbed.

Like many gun control schemes, the San Francisco ordinance applies only to handguns. Two-thirds of all civilian owned firearms are thereby legitimated. This handgun-only ban reflects a common and reasonable judgment that handguns pose a different, more serious, problem than long guns, no doubt because they can be concealed and deployed in surprise attacks. Still, the long gun exemption blows a massive hole in the "control" scenario.

Turning again to the San Francisco ordinance, there are ten exemptions from the prohibitory norm which together allow for the survival of extensive handgun ownership:

(A) Public law enforcement personnel;

(B) Military personnel while employed in the performance of their duties;

(C) Those using handguns on target ranges;

(D) Those transporting target shooting handguns;

(E) Licensed Collectors;

(F) Those who qualify for licenses to carry concealed weapons, and licensed handgun sellers;

(G) Armored vehicle guards who have obtained a Firearms Qualification card;

(H) Patrol special police officers, assistant patrol special police officers, animal control officers or zookeepers, humane officers authorized under $\S 607 \mathrm{f}$, and harbor police;

(I) Guards or messengers of common carriers, banks, and other financial institutions engaged in the course of their duties; guards of contract carriers operating armored vehicles; private investigators, private patrol operators, and alarm company operators; uniformed security guards or night guards employed by any public agency; uniformed security guards, regularly employed and compensated as such by persons employed in any lawful business;

8. Doe v. City \& County of San Francisco, 136 Cal. App. 3d 509, 186 Cal. Rptr. 380 (1982); 65 Cal. Op. Att'y Gen. 457 (1982). The Court in Doe held that the legislature preempted the ficld of licensing and regulating handguns by virtue of Government Code $\$ 53071$. 136 Cal. App. 3d at 51518 , $186 \mathrm{Cal}$. Rptr. at $383-85$. Since the state has occupied the field, an ordinance that requires a larger class of citizens to seek a discretionary license in order to keep their handguns (Penal Code $\$ 12050$ ) is invalid as a licensing ordinance. Id.

9. San Francisco, Cal., Municipal, Code pt. II, ch. VIII, art. 35, 3503 (1982). 
(J) Any person engaged in any lawful business, or any officer, employee, or agent authorized by such person for lawful purposes connected with such business, possessing a handgun within such person's fixed place of business. ${ }^{10}$

Most of what the ordinance's bold opening pronouncement takes away is given back by its exceptions. The public law enforcement exception (A) includes several dozen categories of personnel, such as district attorneys' investigators, alcoholic beverage control officers, investigators for the Department of Professional and Vocational Standards, forest and fire wardens, University of California police, food and drug inspectors, park rangers, and prison guards. ${ }^{11}$ In short, this exception goes far beyond

10. San Francisco, Cal., Municipal Code pt. II, ch. ViII, art. 35, § 3507 (A)-(J) (1982) (the provisions of the ordinance have been paraphrased here).

11. San Francisco, Cal., Municipal Code pt. II, ch. VIII, art. 35, § 3507 (a) (1982) exempts:

Peace officers listed in Sections 830.1, 830.2, 830.3, 830.31, 830.4, 830.5, and 830.6 of the Penal Code whether active or honorably recired, other duly appointed peace officers, full-time paid peace officers of other states and the federal government who are carrying out official duties while in California, or any person summoned by any such officers to assist in making arrests or preserving the peace while such person is actively engaged in assisting such officer.

Peace officers exempted under the applicable California Penal Code sections include: the police of a city or other district permitted by statute to maintain a police force, constables and deputy constables regularly employed and paid by a judicial district, sheriffs, undersheriffs and deputy sheriffs regularly employed and paid as such, marshals and deputy marshals of a municipal court, inspectors and investigators regularly employed and paid as such by a district attorney's office, the Deputy Director, assistant directors, assistant chiefs, special agents and narcotics agents of the Department of Justice who are designated as peace officers by the Attorney General under $\$ 830.1$; members of the California Highway Patrol whose primary duty is the enforcement of the Vehicle Code and other laws relating to the highways, members of the California State Police Division whose primary duty is the protection of state property and the occupants thereof, members of the California National Guard called into active duty, serving where military assistance is required and directly assisting civil authorities where specified by statute, members of the California State University and College Police department whose duties involved enforcement of the law as specified by statute, members of the Law Enforcement Liaison Unit of the Department of Corrections whose duty is the investigation, apprehension, and transportation of parolees, parole violators, or escapees, or the coordination of such activities with other agencies, members of the Wildlife Protection Branch of the Department of Fish and Game whose primary duty is the enforcement of the law as provided by statute, members of the Department of Parks and Recreation designated by the director whose primary duty is the enforcement of the law as specified by statute, and employees of the Department of Forestry designated by the director under $\$ 830.2$; law enforcement personnel regularly employed by the Department of Alcoholic Beverage Control for the enforcement of laws relating to alcoholic beverages designated by the Director of Alcoholic Beverage Control, persons emploved by the Division of Investigation of the Department of Consumer Affairs and investigators of the Board of Medical Quality Assurance, the Board of Dental Examiners, the Department of Motor Vehicles, and the California Horse Racing Board who are designated as investigators, the State Fire Marshal, the Food and Drug Section employed as investigators, the Division of Labor Standards Enforcement employed as investigators, the State Departments of Health Services, Social Services, Mental Health, Developmental Services and Alcohol and Drug Programs and the Office of Statewide Planning and Development, the Bureau of Fraudulent Claims of the Department of Insurance, including the chief and investigators, and the Department of Housing and Community Development under $\$ 830.3$; arson investigators, park rangers, community college police departments, welfare fraud investigators and inspectors, child support investigators, coroners and deputy coroners, members of the San Francisco Bay Area Rapid Transit District Police Department, harbor and port police, and security officers designated by a municipal district under $\$ 830.31$; security officers of the California State Police Division, the Sergeant of Arms of each house of the Legislature, bailiffs of the Supreme Court and of the courts of appeal, guards and messengers of the Treasurer's office, officers designated by the hospital administrator of a state hospital under the jurisdiction of the State Department of Mental Health or the State Department of Developmental Services, railroad policemen commissioned by the Governor, members of a police department of a school district, Security Officers of the County of 
permitting "the police" to retain their handguns; the privilege is extended to almost anyone connected with the criminal justice system, whether or not in front line law enforcement positions. Even these agencies' retirees are entitled to retain their handguns! ${ }^{12}$ Sheriffs and police chiefs retain unfettered discretion to permit private citizens to carry concealed handguns "upon proof that the person applying is of good moral character, that good cause exists for the issuance, and that the person applying is a resident of the county." 13 There is no way of knowing how hundreds of police officials interpret "good moral character" and "good cause."14

Sections (I) and (J) of San Francisco's Handgun Control Ordinance exempt the greatest number of handgun owners. Section (I) allows most private security personnel to possess handguns. Subsection (I) (1)(7) authorizes armored vehicle guards to carry weapons, provided that they pass a brief firearms training course. ${ }^{15}$ Another subsection allows "uniformed security guards, regularly employed and compensated as such by persons engaged in any lawful business" to possess handguns on business premises. ${ }^{16}$

Los Angeles, housing authority patrol officers, transit police officers, and airport law enforcement officers under $\$ 830.4$; corrections, probation, and parole officers under $\$ 830.5$; and persons deputized or otherwise appointed as reserve or auxiliary sheriffs or as policemen, deputy sheriffs, or reserve officers of a regional park district, or deputies of the Department of Fish and Game under $\S 830.6$.

Peace officers appointed under $\S \S 830.3$ through 830.5 may carry firearms only if permitted by their employing agencies.

12. See San Francisco, Cal., Municipal Code pt. II, ch. VIII, art. 35, §3507(A)(1). Under state law, however, the only duly retired peace officers exempt from the concealed weapons violation statute are those employed under $\S \S 830.1$ and 830.2. Cal. Penal Code $\S 12027$ (a) (West 1982).

13. Cal. Penal Code $\S 12050$ (West 1982). In Salute v. Pitches, 61 Cal. App. 3d 557, 132 Cal. Rptr. 345 (1976), the court held that the fixed policy of denying permits under Penal Code $\$ 12050$ constituted an abuse of discretion. 61 Cal. App. 3d at 560, 132 Cal. Rptr. at 347. Apparently officials in San Francisco and Los Angeles still refuse all applications to carry concealed weapons. There are no more than 20 such permits in San Francisco. San Francisco Examiner, June 6, 1983, at B2, col. 4. Statements by the San Francisco police chief suggested, however, that this policy would be relaxed under a handgun ban.

14. This type of "good cause" scheme is not unique. New York law authorizes judges and police officials to grant possession and carry permits to applicants who can demonstrate "good moral character" and "concerning whom no good cause exists for the denial of the license." N.Y. PeNaL Law $\$ 400.00$ (1) (McKinney 1980). In spite of the wording, which seems to presume a liberal approach to awarding licenses, the statute is administered with a heavy presumption against licensing. Case-by-case licensing does not require explicit decisions concerning the priority of different claims. Such judgments are invisible. The result might be less political controversy (assuming generosity in granting permits) because invisible decisionmaking is harder to attack on the merits. On the other hand, such open-ended discretion is vulnerable to arbitrariness, discrimination, and erratic implementation.

15. Armored vehicle guards must obtain a Firearms Qualifications Card from the Department of Consumer Affairs in order to possess a handgun. San Francisco, Cal., Municipal. Code pt. II. ch. VIII, art. 35, $\$ 3507(G)(1982)$. Uniformed security guards, patrol operators and their emplovees. private investigators and their employees, and guards and messengers of financial institutions must be issued a certificate pursuant to $\$ 12033$ of the California Penal Code. Id. $\S 3507(\mathrm{I})(1)-(6)$. The certificate can be obtained by completing "a course in the carrying and use of firearms and a course of training in the exercise of the powers of arrest" offered by any school. The courses must "meet the standards prescribed by the department" of Consumer Affairs. Cal. Penal Cone $\$ 12033$ (West Supp. 1984).

16. San Francisco, Cal., Municipal. Code pt. II, ch. VIII, art. 35, \$3507(I)(5) (1982). 
Section $(\mathrm{J})$ is even broader: it permits handgun possession by "any person engaged in any lawful business, including a nonprofit organization, or any officer, employee, or agent authorized by such person for lawful purposes connected with such business, possessing a handgun within such person's fixed place of business." 17 In other words, any legitimate business person or designated employees may go armed on business premises. The ordinance does not require a firearms training course. ${ }^{18}$

To summarize, the San Francisco Handgun Control Law imposes no restrictions on possession of long guns. It permits handgun possession by active and retired law enforcement personnel, uniformed private security guards, private investigators, business persons (broadly defined) and their employees, and various others. Only private citizens in their residential roles are denied handguns, unless they can obtain permits to carry concealed weapons. On reflection, what is most remarkable about the ordinance is not its bold disarmament initiative, but its recognition of so many instances of firearms possession as inevitable and perhaps justifiable.

\section{B. The Morton Grove Ordinance}

One year before the San Francisco ordinance was passed, Morton Grove, a Chicago suburb, also passed a gun control ordinance. ${ }^{19}$ The impetus for the ordinance was an application to open a gun shop in the community. ${ }^{20}$ Like its San Francisco counterpart, Morton Grove's law received a good deal of national publicity. Unlike the San Francisco law, however, this ordinance survived legal assaults in the state and federal courts. ${ }^{21}$ While it purports to

17. $I d . \$ 3507(\mathrm{~J})$.

18. Neither section $(\mathrm{J})$ nor the mandatory jail sentence for illegal possession of a handgun was part of the ordinance as originally proposed. Carol Ruth Silver, a member of the Board of Supervisors and a critic of handgun bans, put forward an alternative ordinance prohibiting possession of stolen firearms and firearms in bars or while under the influence of alcohol, and recommended that state and federal officials enact mandatory minimum sentences with no plea bargaining or concurrent sentencing for convicted felons illegally possessing firearms. This proposal would have made possession of a firearm without a permit (to be given to any "responsible, law. abiding adult") a felony, required a 72-hour cooling-off period before a purchaser could obtain a firearm, made selling a firearm to any person who did not show a permit or supporting identification a felony, imposed civil liability upon sellers of firearms who did not ask to see a permit or identification or abide by the cooling-off period should any loss or injury occur, and imposed civil liability upon parents whose unsupervised children misused their parents' firearms. The ordinance also would have established minimum mandatory sentences for theft, fencing, or possession of stolen firearms, for illegal carrying of concealed firearms, and carrying firearms in a bar or while under the influence of alcohol. It also would have established programs to teach the public how safely to store and use firearms.

Apparently, the Board of Supervisors was partially persuaded. The ordinance which ultimately passed allowed private citizens in their professional, but not residential, roles to possess handguns: illegal possession was made punishable by imposition of a mandatory jail sentence. See C. SiLver. Handcun Controls Briefing Book (May 11, 1982) (prepared for San Francisco Board of Supervisors).

19. Morton Grove, Ill., Code § 132.102(E)(1)-(10) (1981).

20. Telephone interview with Martin Ashman, Corporation Counsel for Morton Grove, lllinois (July 25, 1983).

21. See Quilici v. Village of Morton Grove, 695 F.2d 261 (7th Cir. 1982), cert. denied. 464 U.S. 863 (1983); Kalodimos v. Village of Morton Grove, 113 Ill. App. 3d 488, 447 N.E.2d 848 (1983). aff d. 
proscribe possession of handguns within village limits, it also establishes a number of important exceptions:

(1) Peace Officers;

(2) Wardens and other jail and penitentiary personnel;

(3) Members of the active and reserve armed forces, and National Guard;

(4) Special Agents employed by a railroad or a public utility to perform police functions; guards of armored car companies; watchmen and security guards actually and regularly employed in the commercial or industrial operation for the protection of persons employed and private property related to such commercial or industrial operation;

(5) Agents of the Illinois Legislative Investigating Commission;

(6) Licensed gun collectors;

(7) Licensed gun clubs;

(8) Those possessing antique firearms;

(9) Those transporting handguns to persons authorized to possess them;

(10) Those transporting handguns from one gun club to another. ${ }^{22}$

The first and fourth exceptions are the broadest. Since "peace officer" is not defined by the ordinance, the definition in the Illinois code is applicable: "Any person who by virtue of his office or public employment is vested by law with a duty to maintain public order or to make arrests for offenses whether the duty extends to all offenses or is limited to specific offenses."23 This definition covers all types of "police forces," including, for example, college and university police forces, security guards for public institutions, and law enforcement officers of state agencies. ${ }^{24}$ The state courts have broadly construed "peace officer" to include any employee of a public entity responsible for maintaining public order. ${ }^{25}$

Prison and jail officers, who do not qualify for peace officer status because they have no general powers of arrest or order maintenance, are allowed to carry concealed weapons while performing some duties and while commuting to and from work. ${ }^{26}$ This exception is curious because guards do not carry

103 Ill. 2d 483, 470 N.E.2d 266 (1984). Unlike the California court in Doe v. City \& County of San Francisco, $136 \mathrm{Cal}$. App. 3d 509, $186 \mathrm{Cal}$. Rptr. 380 (1982), the Illinois state and federal courts found that under state law the issue had not been preempted. Illinois law establishes a presumption in favor of municipal home rule. Quilici v. Village of Morton Grove, 695 F.2d at 267-68. The Morton Grove ordinance also passed state and federal constitutional scrutiny. Id. at 265-67.

22. Morton Grove, Ilt., Cone $\$ 132.102($ E)(1)-(10) (1981).

23. Ill. Rev. STAT. ch. 38, \& $2-13$ (1973).

24. See, e.g., Evans v. Rewers, 595 F.2d 372, 373-74 (7th Cir. 1979) (county hospital security guards are peace officers, but only ". "upon premises operated by the Governing Commission and when required for the protection of such premises, personnel, students, patients and properties thereof ") (quoting Ill. Rev. Stat. ch. 34, 910 (1973)); People v. Picha, 44 Ill. App. 3d 759, 762, 358 N.E.2d 937, 939 (1976) (Southern Illinois University Police Department members are peace officers " $[w \mid$ ithin their defined jurisdiction and subject to certain limitations"); 1981 Ill. Op. Att"y Gen. 89 (certain Department of Revenue fraud agents are peace oflicers); 1980 Ill. Op. Att'y Gen. 73 (University of Illinois police are peace officers, but only when protecting university properties or interests, unless specifically requested otherwise by the appropriate county sheriff).

25. If an employec of a public entity is responsible for maintaining public order, he or she is a peace officer. Peace officer status may extend to all times and all places in the state, or may be limited to a specific time and place. See People v. Bouse, 46 Ill. App. 3d 465, 471, 360 N.E.2d 1340. 1344 (1977) (police officers are peace officers at all times, whether in or out of uniform).

26. Morton Grove, ILl., Code $\$ 132.102(F)(2)(1981)$. 
firearms on the job, except for rifles and shotguns held by those posted in towers.

The fourth exception permits all types of private security guards to possess weapons. In addition to special agents of railroads and utilities, and employees of armored car companies (e.g., Brinks, Wackenhut), all those who guard commercial property are entitled to possess guns and to carry them on the job. ${ }^{27}$ Presumably, they may transport their weapons to and from work.

Unlike the San Francisco ordinance, the Morton Grove law does not provide an exception for business persons carrying handguns on business premises. In the final analysis, however, Morton Grove, like San Francisco, gave its approval to an enormous amount of gun ownership. Such approval gives ammunition to members of excluded groups who are likely to view themselves as equally worthy of an exemption as all those who have been exempted. ${ }^{28}$

\section{III}

\section{The Slippery Slope of Handgun Prohibition Exceptions}

Even purportedly strict handgun control laws would leave long guns untouched and large numbers of people free to possess handguns at home and at work. Those with guns at work may be entitled to commute with their weapons. A smaller number of people are permitted to carry handguns at all times. What justifies these exceptions?

\section{A. Long Guns}

Because long guns are more difficult to conceal, they may be less deployable for some kinds of crimes, like street robberies. They can be (and are) used to commit crimes and "settle arguments," however, and if accidently discharged they can cause great damage or death. They are much more deadly than handguns. A handgun-only prohibition would lead some handgun owners and would-be owners to replace their handguns with much more powerful rifles and shotguns. Whether more long guns and fewer handguns would reduce gun violence depends upon how many and what types of handgun owners make the switch to long guns. It is tempting to conclude that the exemption of long guns from proposals for firearms prohibition primarily reflects a judgment about political reality. Long gun owners are a much more powerful political group than handgun owners (although many owners possess both types of weapons). The fact that long

27. Id. \$132.102(E)(4).

28. In fact, the plaintiffs in Kalodimos v. Village of Morton Grove, 103 Ill. 2d 483. 470 N.F.2d 266 (1984), did make this argument. The Illinois Supreme Court observed that "liln relatled contentions, [the plaintifls] argue that the ordinance, through its exemptions. arbitrarily discriminates between residents of the village in violation of equal protection guarantees . . . . $l d$. at 494, 470 N.E.2d at 277. The court upheld the law. Because the state right to bear arms is not fundamental, the ordinance need only have a rational basis to withstand constitutional equal protection scrutiny. 
guns are used for hunting also gives them a "legitimate" purpose that handguns (in the eyes of many) do not have.

\section{B. The Peace Officer Exception}

The exception to general handgun prohibition that enjoys the greatest consensus is the exception made for "the police." 29 Even fervent advocates of handgun control (including police themselves) concede that under stringent handgun control the police will continue to possess and carry handguns. ${ }^{30}$ This concession should not go unquestioned. It may well turn out that there is a relationship between arming the police and arming the general citizenry. ${ }^{31}$

Curiously, gun control advocates have not urged the police to give up their handguns in order to achieve a complete prohibition. If even the police (or some portion of them) were denied handguns, the force of the prohibitory norm would be very strong indeed. A society that denied, seriously limited, or even seriously questioned the need for police handguns would be unquestionably committed to eliminating this weaponry.

To speak of "disarming" the police of their handguns does not convey any indication as to what weapons the police would be allowed instead. Just like civilians, the police might arm themselves with rifles or shotguns under a handgun-only prohibition. Would that be desirable? The answer depends upon the comparative advantages and disadvantages of these high-powered

29. For a brief history of police firearms policies, see Morn, Firearms Use and the Police: A Historic Evolution of American Values, in Firearms and Violence: Issues of Public Policy 489 (D. Kates ed. 1984) [hereinafter cited as Firearms and Violence]. Morn argues that an armed police emerged in the second half of the 19 th century as a response to increased use of firearms by criminals. Id: at 500 12.

30. The National Coalition to Ban Handguns recognizes that even under a "ban," law enforcement personnel will keep their handguns. "A ban on the private possession of handguns does not mean that no one may own a firearm . . . . The police and other law enforcement officials will still have access to any firearms they need, including handguns." National CoALition to BaN Handguns, supra note 4 , at question 13 .

31. Cf. D. Bayley, Forces of Order: Police Behavior in Japan and the United States 160 (1979):

It is clearly unrealistic to expect any police force to disarm if the populace at large is allowed to possess substantial quantities of firearms. At the same time, willingness of the police to use firearms may affect the way guns are viewed by society. Specifically, the fact that police accept the inevitability of armed confrontations with offenders may reduce pressure for more stringent gun control laws. Consider, for instance, what would happen if American police officials publicly announced their commitment to strict gun control legislation and then announced they would disarm themselves as an example of how safe society is most of the time. The immediate reaction, of course, would be astonishment and incredulity. The long run effect would be to make the killing of policemen wanton acts. If policemen were unarmed and then killed, the implicit norms of fairness would be violated. They wouldn't have a chance. The public would have a greater difficulty than now in denying responsibility for protecting police officers. Support for strict enforcement of penalties against guns in crime would stiffen, as would pressure for hand gun control legislation. Guns in police hands and guns in private hands are related. But there is more symmetry in the relationship than is usually recognized. The police will feel compelled to be armed as long as much of the populace is. But the populace may not limit arms ownership without persistent encouragement from the police, especially willingness to sacrifice some of the appearance of self reliance. The police probably possess more initiative than they are willing to exercise. 
weapons. They might well be too unwieldy for effective deployment in many police encounters; whenever they are fired, the chance of death or serious injury is greater than when handguns are used. It is conceivable, however, that their greater firepower would better deter criminal violence and attacks on police, thus producing fewer fired shots.

Instead of "trading up," the police could be forced to "trade down," and make do with rubber or plastic bullets, tasers or stun guns, or blackjacks and mace. ${ }^{32}$ It seems extraordinary that there has been so little thinking about and experimentation with weapons other than the traditional handgun. Creative experiments in "arming down" might contribute to a social and political environment in which civilian gun ownership would lose some of its attraction.

Whether or not prohibiting police handguns is politically conceivable, virtually all handgun prohibition proposals, like the San Francisco and Morton Grove ordinances, exempt the police. Why? Surprisingly little attention has been given to this question. Illuminating the reasons for the police exemption might be of assistance in discerning the core rationale that justifies or defeats other claims for exemptions from handgun prohibition. In other words, why should the police be armed and the general citizenry or various discrete groups of citizens be disarmed? Four plausible reasons are: 1) personal safety; 2) arrest powers; 3) deterrence of crime; and 4) superior training and judgment.

1. Personal Safety. The extent to which personal safety justifies handgun ownership is central to the handgun controversy, since many persons own handguns in order to defend themselves. If self-defense provides the crucial justification for permitting police to carry guns, why does personal security not justify handguns for everyone? Are the police in greater danger than other citizens? Are firearms a more effective and appropriate means of selfdefense for police than for other citizens? Are private citizens better situated than police officers to absorb the risks of unarmed self-defense? Are the "costs" of police firearms less than the "costs" of civilian firearms?

It is true that an unarmed police officer might be at the mercy of an offender armed with a gun (knife, tire iron, etc.), but so too might an unarmed store owner, apartment dweller, or pedestrian. ${ }^{33}$ The police officer is likely to

32. Siun guns are small battery-operated devices with two electrodes all one end. When pressed against a person's body or clothing. they release an clectric charge that causes temporary loss of neuromuscular control and collapse. Ihe taser is similar to a stun gun. It shoots two darts atlached to long wires: when the darts strike the larget's body, the shock is administered.

33. The potential effectiveness of gum control laws in kecping handguns away from criminals has excited a good deal of controversy. lior a discussion of problems associated with the enforcement of guu control laws against criminals. sec Cook \& Blose. Stale Programs for Sirepring IImmlgum Buyms, 455

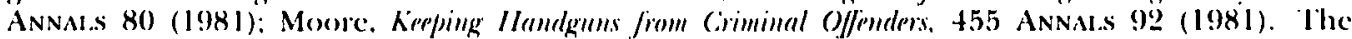
problems involved in reducing the stock of handguns in the general population ate surveyed in

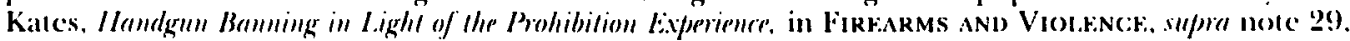

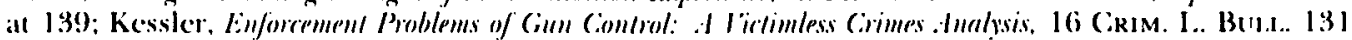
(1980). If criminals responded to a handgun ban by substituting sawed-ofl sholgums and rifles for handguns, the result might be a larger number of fatalities. Sire Hatrdy \& Katcs. Mlamdgun In'rilability 
come into contact with dangerous offenders more frequently than most, but not all, private citizens, some of whom live in dangerous neighborhoods (and public housing projects) where they are highly vulnerable to attack. ${ }^{34}$ Arguably, the police officer has fewer self-defense options than the private citizen, because the officer cannot avoid dangerous areas, streets, and taverns, and cannot flee from potential assailants. There is some force to this point, but only some. Many private citizens, among them the elderly, poor, weak and powerless, lack realistic options for avoiding attacks and defending themselves. Some of these people could plausibly claim that the state has created their vulnerability by its maladministration of public housing or public transportation and by its ineffective criminal justice system. ${ }^{35}$

and the Social Harm of Robbery: Recent Data and Some Projections, in Restricting Handguns: The I.iberai. Skeptics Speak Out 126-29 (D. Kates ed. 1979); Kleck, Handguin Only Gun Control: A Policy Disaster in the Making, in Firearms and VIOLENCE, supra note 29, at 171.76.

For study reports and critiques that measure the efficacy of handgun controls in reducing violent crime, see Hardy, Firearm Ownership and Regulation: Tackling an Old Problem with Renewed Vigor, 20 WM. \& MARY L. REv. 235 (1978) (critiquing criminal armament studies as well as ownership surveys and programs aimed at eliminating criminal gun use); Jones, The District of Columbia's "Firearms Control Regulations Act of 1975": The Toughest Handgun Control Law in the Linited Siates-Or Is It?, 455 ANNALS 138 (1981) (critique of United States Conference of Mayors' assessment); Pierce \& Bowers, The Bartley-Fox Gun Law's Short-Term Impact on Crime in Boston, 455 Annals 120 (1981). The inefficacy of current handgun bans illustrates a crucial point: it would be virtually impossible to confiscate handguns owned by criminals, even under a universal ban.

34. In a recent New York gun possession case, the defendant, a 53-year-old "law-abiding citizen," had lived for 17 years in a city-owned housing project in the Bronx, a neighborhood which had become increasingly dangerous and crime-ridden. He testified that he had purchased an out-ofstate gun in response to the "litany of terror" that his family had lived through as a result of attacks on them and their home. The court granted the defendant's motion to dismiss the indictment for criminal possession in the third degree "in the interest of justice." People v. Hamilton, N.Y.L.J., Jan. 30, 1985, at 7, col. 3, 11 , col. 3 (Sup. Ct. Jan. 29, 1985).

35. Perhaps this line of inquiry proves too much. Does it not suggest that the self-defense rationale should expand the opportunity for citizens in good standing to cary handguns for selfprotection? Is there any reason to think that the average citizen is less vulnerable on the streets or in the subways than at home? One should not so easily dismiss the fears of men and women who have to commute to work in dangerous neighborhoods. If the point is to maximize safety, why should the individual not be permitted to carry a concealed or visible handgun on his or her person, like a police officer?

The argument for prohibiting people from carrying weapons on the streets is far stronger than the argument for prohibiting possession of handguns. A home weapon is primarily defensive. and the circle of those who can be injured by its misuse is narrowly circumscribed. Of course, weapons purchased for "home use" can and will be carried outside the home by some portion of owners. A wcapon carried in public may deter attacks, if it is seen or suspected, but in case of a surprise attack, the handgun may be of little or no assistance, even to a police officer. More important, a gun carried in public can also be used offensively to commil crimes. A handgun can be deploved very quickly to rob a pedestrian or a store clerk, or to kill any civilian or police officer. Social life would be enormously insecure if everyone carried a firearm at all times. As a consequence, there is a strong socictal interest in limiting as much as possible the number of people who are allowed to carry a handgun in public.

The right to carry a weapon in public, sometimes concealed, has already been extended berond the public police. Some private security officers, like university police, regularly carry weapons, as do some probation officers, parole officers, and court personnel. Private security guards who are athorized to carry weapons at work frequently carry their weapons off duty, since there is no place to store them on the job, or merely because they like to carry a gun. This means that they mas frequently be armed in public. Influential persons are able to obtain carry permits for themselves or their bodyguards under criteria of special need or good cause. 
On the other hand, the police officer might argue that his or her claim to bear arms is especially compelling because the state creates the officer's vulnerability by organizing a public agency charged with keeping the peace and enforcing the laws-hazardous activities to be sure. The handgun might be for the police officer what protective goggles are for the welder. ${ }^{36}$ Even so, asking police officers to assume greater risks than ordinary citizens is morally permissible. The police cannot be protected against all risks. They cannot be encapsuled in bulletproof bubbles and made invulnerable to snipers, maniacs, and drunk drivers. Fortunately, gun attacks on police officers are still rare, even in big cities. In addition, it is not totally far-fetched to hypothesize that some gun attacks may occur precisely because police project an aggressive armed presence. A significant number of police officers each year mistakenly shoot other police officers, and some are victims of their own gun accidents. ${ }^{37}$

Prison and jail guards work unarmed every day among men proven to be violent and dangerous, some of whom are either "lifers" or very long-term prisoners with little to fear from new criminal charges. In a typical exercise yard or cell block a guard vastly outnumbered could be stabbed, bludgeoned, strangled, or otherwise eliminated at any time; yet there is no move to arm jail and prison guards. It seems odd that so much attention is paid to minimizing the risk of attacks on police, but not on prison officers.

The police are surely in a much better position than civilians to develop alternative protective technologies and strategies. While the future of police weaponry is beyond the scope of this article, the police are well positioned to experiment with all sorts of nonlethal weapons, to outfit themselves in bulletproof clothing, and to train themselves in martial arts. Even without any developments along these lines, an unarmed police officer is probably more adept at self-protection than a private citizen because he or she is likely to be better trained in self-defense, to carry a night stick, chemical mace, and other weapons, to travel with another officer, to have recourse to reinforcements, and to be alert to potential trouble. In deterring assaults, the officer can rely upon the state's moral authority and the widely shared knowledge that prosecutors and courts regard assaults on police officers more seriously than assaults on private citizens. ${ }^{38}$ Why, then, should the police officer be

36. See, e.g., Oakland Police Officers Ass'n v. City of Oakland, 30 Cal. App. 3d 96, 100-01, 106 Cal. Rptr. 134, 138 (1973) (there is a legislative duty on the part of the city to provide police officers with "safety equipment," including a service revolver). The court in Oakland Police Officers said, "the fact that the gun protects the officer's life does not make it less important as a safety device than the goggles which guard a workman's eves. . . . It is unthinkable that a local govermment agency would require or permit its offerew to go onto the streets atithout gums." Id. at 100-01, 106 Cal. Rptr. at 138 (emphasis added). But spe D. BAYley, supra note 31, at 172 ("When the police [in Japan] deploy to handle riots and demonstrations they deliberately disarm themselves. Rather than breaking out new and more deadly forms of weaponry, as American police do. they take off their pistols and leave them at the police station.").

37. See Geller \& Karales, Shootings of and br Chicago Police: L'ucommon Crises, Part II: Shootings of Police. Shooting Correlales and Comtrol Stralegies, 73 J. Crim. L. \& Criminologr 331.332 (1982).

38. Indecd, in many jurisdictions assaulting a law enforcement officer is an aggravated form of assault. E.g. Cal. Penai. Code $§ 243$ (West Supp. 1984). 
permitted to carry a handgun, but the private citizen be prohibited, perhaps on pain of imprisonment, from even keeping a handgun in his home?

In sum, advocates of handgun prohibition cannot justify an exception for the police on self-defense or safety grounds without letting loose tremendous pressure to recognize other self-defense and safety claims that could ultimately swallow up the prohibition.

2. Arrest Powers. The police are authorized to arrest when they have probable cause to believe an individual has committed an offense. To take an offender into custody the police arguably need special powers. Perhaps the need to make arrests, more than a special need for self-protection, distinguishes the police officer from the private citizen. ${ }^{39}$ Does the authority and responsibility to make arrests support a special claim to carry firearms? If so, this is a much narrower justification than safety and security, and one that might distinguish the police from other citizens wishing to possess firearms.

Proof is lacking, however, on the extent to which police officers do need handguns in order to take suspects into custody ${ }^{40}$ Americans, accustomed as they are to a thoroughly and continuously armed police (and to constant television and movie depictions of shootouts), may find it hard to imagine that police could carry out their duties without handguns. ${ }^{+1}$ In part, this difficulty is because the popular image of "the police" is shaped by those who patrol the toughest areas of America's largest cities, precisely the officers who have the most need to be armed. Tens of thousands of officers work in rural and suburban environments far less dangerous than the violence-ridden neighborhoods of large cities. It is hard to believe that the need to make arrests could justify arming all of these personnel at all times on all assignments. Some officers have duties that never bring them into confrontational situations; for them a holstered handgun is part of the uniform, perhaps indicative of status but not a functional necessity. Their psychological investment in the need to be armed is similar to that of many civilians who feel just the same way.

Whether patrol officers need firearms to make arrests is worth examining. There may be a good deal of exaggeration of such need, especially in suburbs, towns, and villages with low rates of violent crime. Self-defense skills, moral

39. In Arrington v. (ity of (Chicage, 45 Ill. $2 \mathrm{~d} 316.259$ N.K.2d 22 (1970), the Illinois Supreme Court declared:

A peace officer is defined as any person who by virtue of his oflice or public cmployment is vested by law with a duty 10 maintain public order or 10 make arrests for offenses. . . He hats the duty to mainain public order wherever he may be: his duties are nol confined a a specilic time and place as are those of a prison guard. It is for this reason and nol brectesese a prener officer may

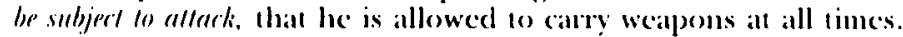

1d. at 318, 259 N.F..2d at 24 (cmphasis adeded) (citation omitted).

40. Other avenues of force are available. According 10 sociologist kgon Bituner, "the police have a monopoly on non-negotiable coercive fonce emploved in accordance with the dictates of an

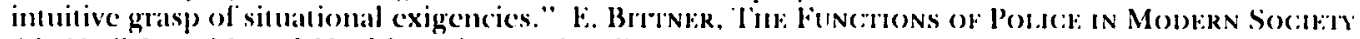
46 (Nat'] Inst. Mental Health, Grime and Delinequency Issues Menogtaph Series No. 2055) 1970).

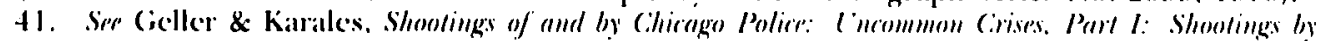

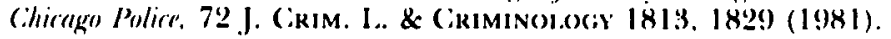


and legal authority, and availability of reinforcements might enable officers to make arrests in most cases, even if they were not armed. Police effect most arrests in Great Britain and Japan without the use of guns. ${ }^{42}$ Even in large American cities, police officers very rarely draw their guns, although admittedly the visible presence of a gun might deter the kind of attacks that would make it necessary to draw.

The relationship between being armed and being able to make an arrest is hardly obvious. ${ }^{43}$ Many jurisdictions and police departments sharply limit the right to use deadly force to make an arrest. Some states follow the Model Penal Code in authorizing the use of deadly force to arrest only when an officer reasonably believes the suspect has committed a violent felony or threatens death or serious bodily harm if the arrest is delayed. ${ }^{44}$ Many police departments go much further in restricting the use of deadly force. ${ }^{45}$ In many large cities an investigation is automatically called for any time deadly force is used. ${ }^{46}$ Increasingly, rules governing police use of deadly force prohibit the use of firearms to make arrests in all but the most desperate situations. How does being armed help in making an arrest? Will a suspect acquiesce in being taken into custody if he knows that he could be shot if he tries to flee? In the recent case of Tennessee v. Garner, the United States Supreme Court held Tennessee's law permitting the police to shoot any fleeing felon to be unconstitutional, reasoning that "[i]t is not better that all felony suspects die than that none escape. Where the suspect poses no immediate threat to the officer and no threat to others, the harm resulting from failing to apprehend him does not justify the use of deadly force to do so." 47 Thus, a handgun will not be of any use in a large number of arrest situations.

Undeniably, there are situations in which dangerous armed felons must be apprehended who would not acquiesce without the threat of lethal force.

42. Police officers in Great Britain are not issued firearms as standard equipment. They are trained to use firearms, however, and police agencies have a wide variety of weapons at their disposal. Law Library, I.ibrary of Congress, Gun Control Laws in Foreign Countries 75-99 (1981). Although Japanese police carry frearms while they are on regular patrol duty, their weapons are rarely used. D. BAYLEY, supra note 31 , at 162 . Riot and undercover police do nol carry guns, and those officers who are armed on duty neither carry guns off duty nor take their guns home. Id. Japanese police rarely need firearms because few private citizens own firearms and the rate of armed crime is very low. Id at 168-69. Furthermore, Japanese police forces, unlike their American counterparts, emphasize tactics and martial arts training. Id. at 163-64. Of course, the point of this article is that, while it mav be difficult to disentangle cause and effect on this issue, restricted police use of firearms may contribute to lower rates of citizen use.

43. As the Supreme Court majority said in Temlessee v. Gamer: "And while the meaningful threat of deadly force might be thought to lead to the arrest of more live suspects by discouraging escape attempts, the presently available evidence does not support this thesis." $105 \mathrm{~S}$. Ct. 1694. 1700-01 (1985).

44. Model Penal Code $\$ 3.07(2)$ (1980).

45. See the extensive discussion of administrative regulations liniting the police officer's right to use deadly force to make an arrest in the Police Foundation's amicus brief in 'Tennessee $v$. Garner. 105 S. Ct. 1694 (1985). See also Geller \& Karales, supra note 37. at 372-73.

46. Geller \& Karales, supra note 41 , at 1829 .

47. Tennessec v. Ganner, 105 S. Ct. 1694, 1701 (1985). 
Still, this type of situation does not justify arming all police all of the time. ${ }^{48}$ Firearms could be assigned selectively, "as needed," to police officers investigating serious offenses or violent offenders, or firearms might be assigned routinely to patrols in certain dangerous neighborhoods or even to all patrols in the largest cities. A police firearms policy that required a showing of need before a firearm was issued would reflect a powerful societal commitment to restrict the use of handguns. ${ }^{49}$

Even if there is justification for drawing a bright line between possession of handguns by the police and by the citizenry, does it extend to police officers' right (or obligation) to carry weapons while off-duty?50 Is a police officer who is off duty and out of uniform sufficiently distinct from a private citizen to justify allowing arms to the former but not the latter? The answer is quite likely "yes." Off-duty police officers in plain clothes are authorized and frequently required to make arrests when they observe the commission of a crime. ${ }^{51}$ There are obviously strong reasons to encourage this policy. It does, however, represent a broad interpretation of the police firearm exemption, and a large percentage of police shootings occur in off-duty situations. ${ }^{52}$

A further option is the possibility of "de-arming." If it is granted that police officers need handguns, what kind of guns and what kind of bullets are required? Should police officers be "armed to the teeth" in order to maximize the possibility of "neutralizing" any threat, or should they "make do" with the least lethal weaponry they are likely to need? Police weaponry of all kinds has apparently increased in caliber, destructiveness, and "stopping power" over the last several decades. Like the international arms race, there seems to be an inexorable drive to accumulate more powerful weaponry. An issue the Supreme Court did not reach in Tennessee $v$. Gamer ${ }^{53}$ is the constitutionality of the "dum-dum" bullets used by the Memphis Police

48. It might also be argued that arrest authority cannot be used to distinguish the police officer from the private citizen because private citizens do have authority (albeit not the obligation) to make an arrest when a felony is committed in their presence. Citizen's arrest is exercised quite infrequently in the United States, although particular categories of private citizens, like security guards, do often detain criminal suspects. See M. Bassiouni, Citizen's Arrest: The Law of Arrest. Search and Seizure for Private Citizens and Private Police 23-26 (1977). The different arrest authority of police and private citizens could serve to justify a police-only handgun exemption.

49. Sadly, the trend is not in the direction of disarming to the greatest feasible extent; rather, it is in the opposite direction. The pressure is to purchase more powerful and lethal handguns and other powerful firearms. Apparently, many police officers in larger cities regularly carry three handguns, one in a side holster, one in an ankle holster, and one in their belt.

50. See Police Foundation, Police Use of Deadly Force (1977); Fyfe, Always Prepared: Police Off-Duty Guns, 452 Annals 72 (1980). Although a Police Foundation survey reveals that $49 \%$ of jurisdictions surveyed require that their officers be armed while off duty, $41.5 \%$ of off-duty weapons discharges by New York City police from August 1972 to December 1975 resulted in some administative or criminal sanction.

The courts have reinforced the notion that the police officer's role continues around the clockwhether on or off duty. See, e.g., People v. Weaver, 100 Ill. App. 3d 512, 514,426 N.F.2d 1227. 1229 (1981) (A peace officer's duty is "not confined to a specific time and place.").

51. People v. Weaver, 100 Ill. App. 3d 512, 514, 426 N.E.2d 1227, 1229 (1981).

52. Geller \& Karales, supra note 37 , at 335 .

53. 105 S. Cı. I694 (1985). 
Department. A comprehensive "gun control" program would aim to reduce the destructive power of police weaponry as much as possible.

3. Deterring Crime. Some people might justify a police-only handgun exemption on the ground that an armed police depresses crime by inhibiting would-be criminals from violating the law. For the deterrence proposition to be true, there would have to be potential offenders who would commit crimes but for fear of being shot by the police or of being arrested by armed (but not unarmed) police. It seems unlikely that the number of such potential offenders is very large, but if it is, is it not also plausible that an armed citizenry, or at least a partially armed citizenry, also serves to deter crime? Potential offenders might fear being shot or arrested by armed civilians as much as by armed police. Indeed, they might fear an armed citizenry more because it is less identifiable and predictable. ${ }^{54}$

4. Superior Training. It will surely occur to some readers that, due to background and training, police officers handle firearms more carefully and responsibly than private citizens. However, this assumption may not be as justified as it might at first seem. Most police officers receive little entry-level weapons training, especially in night firing, and annual requalification requirements are rare. ${ }^{55}$ Very few departments have the resources and facilities to provide effective training in confrontational situations. Unnecessary off-duty shooting and accidents are a significant problem, at least in some departments. ${ }^{56}$ Even if the police as a group are more competent than private gun owners, however, it begs the question to base a weapons policy on police officers' superior training since current public policy discourages weapons training for civilians. If private citizens were willing to submit to the same training as police, and to abide by the same rules (or even more stringent ones) on the use of deadly force, could the police officer still claim

54. According to Kleck and Bordua, burglars and robbers fear homeowners with guns and their fears are justified: "[P]rivate citizens seem to use guns (legally) to shoot criminals about as often as police do." Kleck \& Bordua, The Factual Foundation for Certain Key .Issumptions of Gun Control. $5 \mathrm{LAw1}$ \& POL'Y Q. 271, 283 (1983)

55. Even in large cities, there is great variation in the quantity and quality of weapons training. Sixty-six percent of officers on forces of cities with more than 50,000 residents do not have to qualify with the ammunition they use while on duty. Sixty-seven percent of the forces do not provide training in night firing and $40 \%$ give no field instruction on when to fire. Teske \& Niksich, Firearms Training for Law Enforcement Personnel, Polıce Chicf, Oct. 1979, at 58, 60, 62. Night firing training is particularly important because the majority of shootings occur at night. See Geller, Deadly Force: IITal We Know, 10 J. Police Sci. \& AD. 151, 158 (1982). Morcover, police in general have little incentive to develop firearms skills.

Another measure of police officer training is police use of deadly force. Estimating the frequency of unjustified deadly force is complicated by present recording procedures. See Sherman \& Langworthy, Measuring Homicide by Police Offeers, 70 J. Crim. L. \& Criminolocy 546 (1979) (discussing various factors which tend to minimize the number of police homicides reported).

Several studies suggest that a high proportion of all police homicides are unjustified. Sec Geller. supra, for a summary of most of the pre-1982 major studies on police homicide. In light of such studies, it should not be assumed that police use handguns more safely and responsibly than privatc citizens.

56. Geller \& Karales, supra note 41 , at 1838. 
to be more reliable in possessing and carrying a handgun than is the private citizen in keeping a handgun at home ${ }^{57}$

As for judgment, reliability, and overall moral character, while a prior felony conviction or mental illness disqualifies applicants for police jobs, recruits must merely pass minimum scrutiny; in no sense are they chosen on the basis of superlative psychological stability or moral character. After joining the force, there are no further background checks and investigations in most departments unless charges of corruption or abuse of force arise.

5. Summary. Should the police retain their handguns because the benefits of crime prevention and control outweigh the costs of crimes committed and accidents caused? If so, are the police the only subgroup for which costbenefit analysis would support gun possession? Other groups or individuals would surely claim that their gun ownership provides a net benefit to society-small shopowners, for example, might be able to show that as a class they deter and thwart more harm with their weapons than they cause. If it is accepted that police need powerful handguns (and dum-dum bullets) on an around-the-clock basis, in all types of departments, and on all assignments, it would not be surprising if large numbers of people concluded that they were unsafe, that guns enhance personal security, and that, like the police, they should be armed.

A plausible justification for a police exception to a general prohibition on handguns could emphasize the arrest and order-maintenance responsibilities of the police, and the sense of security an armed police provides for the whole citizenry. If this justification were employed, it would be important not to permit further exceptions lest the legitimacy of handgun prohibition itself be underminded. The next section illustrates, however, that even handgun prohibitionists now seem to accept the arming of other "peace officers" and private security personnel.

\section{Defining "The Police"}

Assuming that there is a strong justification for exempting the police from a general handgun prohibition, which personnel in which departments constitute "the police"? The state police agency, county sheriffs' departments, and city police are obviously included within any definition because they exercise comprehensive law enforcment authority within their jurisdictions. Should the definition include university police, housing and transit police, the investigatory personnel of agencies having authority over

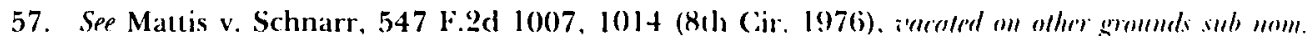

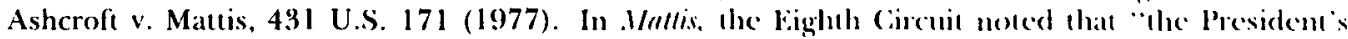

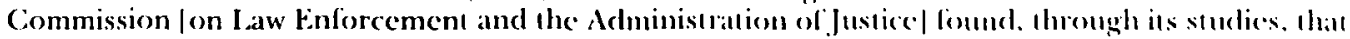
'Ip|olice use of firearms to apprehend stuspeces oficon strains commumity relations of even results in serious disturbances. . . . When studied objectisely and uncmolionally, paticulat use's of lireams by police officers are ofien unwarranted." ' lol. 
pollution control, liquor licensing, and protection of fish and wildlife, parole and probation officers, prison guards, and court personnel? ${ }^{58}$

1. University Police. Consider the university police, most of whom are now armed. ${ }^{59}$ In many states, they exercise police authority on their respective campuses. ${ }^{60}$ Many campus security forces carry out patrol functions in marked squad cars. These departments may have emerged because of a desire to keep the regular police off campuses in the riot and demonstrationfilled days of the 1960's, but they have since justified themselves as a necessary counterforce to predatory crime. Over the years many departments, even those of rural private universities, have armed their personnel with handguns.

In support of their claim to remain armed, campus security forces could emphasize their organizational, legal, and functional similarity to the public police. The campus forces are organized according to the public police model; they wear police uniforms and operate marked patrol cars, and their top personnel typically are recruited from the ranks of law enforcement. University police would oppose their disarmament on the ground that it would undermine their capacity to protect their student communities. College and university faculty, students, and staff might feel insecure without armed protection, reflecting the belief that police without guns are simply not "real police." If general jurisdiction police need handguns to protect their constituents, so the argument goes, university police need guns to protect theirs.

To fold campus security forces into the police exception is to take another step toward loosening the moral force behind a handgun prohibition, dooming any prospects of general disarmament. None of the reasons that

58. Many categories of public employees are considered peace officers. See. P.g. (ail.. Prisil. Codf $\$ 830.1$ - .6 (West 1973); N.Y. Crim. Proc. LAw \$ 2.10 (Mckinney 198.3) (mam ol ihese peace officers must have licenses 10 carry firearms under $\$ 400$ of the Penal 1 .aw). The Illinois delinition. supra notes $22-25$ and accompanying text, includes a diverse group of personnel charged with law enforcement

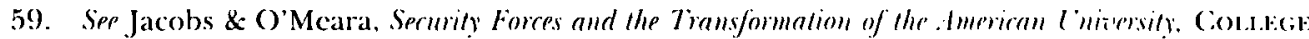
\& U., Spring 1980, at 283. A 1972 survey of 234 campus security forces indicated that 155 of 1 hem issucd fircarms. Id. at 287 n. 15 .

60. A 1972 survey of 234 campus security departments indicated that 111 exercised state authority, 36 excrcised commy atuhority, and 46 exercised cily atulhorits. Id. al 285 11.8 .

In California, for example, Califormia State University and College police are peace oflicers under

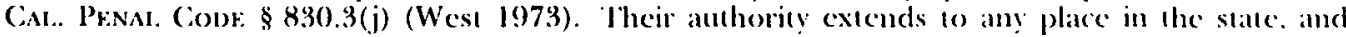

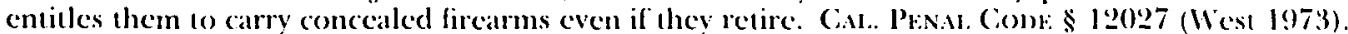

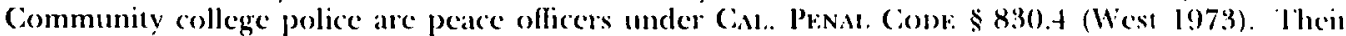
jurisdiction is more limited, and their retired oflicers are not exempl from the concealed liteallms

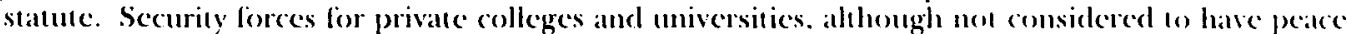
officer status, may be gramted powers of arrest if a memorandum of umderstanding is filed with the

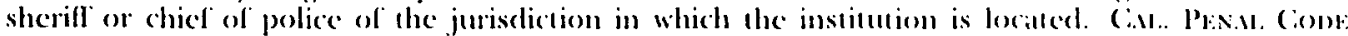
$\$ 830.7$ (West Sitjp. 1983)

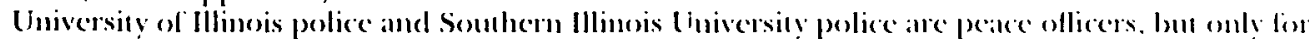

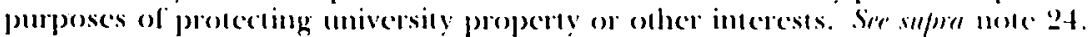

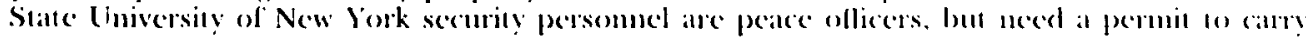

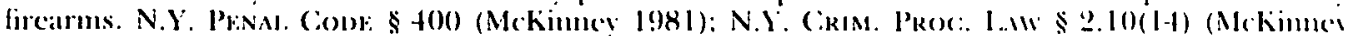
$1981)$. 
support an exception for sworn public police are compelling when applied to most college and university security forces. Self-defense is not a major concern; there is no need to press forward with arrests; there is no special need for an extraordinary deterrent capacity; and there is no reason to consider the personnel of such agencies especially reliable handgun owners and users. If campus police need guns around-the-clock, the general citizenry, including many young people, will consciously or unconsciously conclude that the social environment is dangerous practically everywhere, and that guns are a means of insuring personal security. Widespread acceptance of such a conclusion would doom the prospects of a gun prohibition program.

\section{Other Criminal Justice Personnel. Consider the handgun claims of such} nonpolice personnel as probation and parole officers and prison guards. They do not carry out a police function, although they typically perceive themselves as working in law enforcement. ${ }^{61}$ In many states, they have fought hard, and frequently successfully, for the right to carry weapons on and, in some cases, off duty. ${ }^{62}$

Some prison and jail guards are permitted to possess and carry handguns off duty; ${ }^{63}$ where this is not true, almost invariably there are efforts to secure the privilege. For some officers, the right to carry a weapon may be a major

61. Corrections, probation, and parole officers have peace officer status in some states. See, e.g. Cal. Penal Code $\$ 830.5$ (West 1973); N.Y. Crim. Proc. Law \$ 2.10(23) - (25) (Mckinney 1981 ).

62. Such officers often resort to litigation when their departments seek to limit their guncarrying authority, or they may claim such authority as a defense to an illegal firearms charge. See, e.g. California State Employees' Ass'n v. Way, 135 Cal. App. 3d 1059, 185 Cal. Rptr. 747 (1982) (Department of Youth Authority parole officers unsuccessful in bid to obtain firearms as safets equipment); California State Employees' Ass'n v. Enomoto, 118 Cal. App. 3d 599, 173 Cal. Rptr. 517 (1981) (parole officers denied use of firearms); Arrington v. City of Chicago, 45 Ill. 2d 316, 259 N.E.2d 22 (1970) (corrections officers' attempt to invalidate Chicago ordinance restricting carrying of firearms to on-duty hours successful to extent ordinance conflicted with a newly amended statute allowing possession of weapons while commuting to and from work); People v. James. 54 Ill. App. 2d 361,204 N.E.2d 134 (1964) (Illinois corrections officer successful in quashing indictment relating to his carrying of firearms while off duty: the legislature later amended $\$ 24-2$ of the Penal Code so that corrections officers are exempt from concealed firearms statute only while on duty or while commuting to and from work); Civil Serv. Employees' Ass'n v. Narcotic Addiction Control Comm'n. 45 A.D.2d 685. 356 N.Y.S.2d 618 (1976) (narcotic parole officers not entitled to carry firearms while on duty); Salata v. Tolman, 38 A.D.2d 99I, 329 N.Y.S.2d 427 (1972) (New York City probation officers unsuccessful in overturning regulation barring on-duty firearms): Vasquez v. Connelie. 116 Misc. 2d 29, 455 N.Y.S.2d 76 (1982) (federal corrections officer not exempt from prosecution for carrying firearm off duty); Figaro v. Ward, 86 Misc. 2d 530, 383 N.Y.S.2d 529 (1976) (corrections officers unsuccessful in attempt to invalidate regulation restricting types of handguns which can be carried while off duty); People v. Simmons, 85 Misc. 2d 623, 380 N.Y.S.2d 964 (1976) (narcotics corrections officer indicted for carrying firearms); 64 Cal. Op. Ati'y Gen. 859 (1981) (retired corrections officers unsuccessful in attempt to obtain exemption from concealed firearms statute); 63 Cal. Op. Att y Gen. 385 (1980) (corrections officers successful in obtaining right to carry firearms off duty, but Penal Code later amended to allow employing agencies to abridge this right): $1981 \mathrm{Ill}$. Op. Ally Gen. 48 (probation officers are not peace officers and therefore have no right to carry firearms while on duty).

63. See, e.g. Cal. Penal Code \& 830.5(b) (West 1970); I.l.. Ann. STat. ch. 38. \$ 94-2(a)(2) (Smith-Hurd 1977); N.Y. Crim. Proc. LAw \$2.10(25) (McKinney 1981); N.Y. Penal. I.AW $\$ 400.00(2)(\mathrm{c})$ (McKinney Supp. 1984). 
attraction of their job. Yet prison personnel have no special arrest powers. ${ }^{(i 4}$ If asked to explain why they should be privileged to carry concealed handguns, most jail officers ${ }^{65}$ as well as probation and parole officers, would probably say that they are more likely than the average person to be victimized by ex-inmates harboring grudges against them. ${ }^{66}$ This argument sounds like the concern for personal safety and security shared by many private citizens.

Presumably, the same notion of special vulnerability to attack underlies laws which allow some court officials to carry or possess firearms. California marshals and deputy marshals of a municipal court, as well as constables and deputy constables of a judicial district, have peace officer status and can carry concealed firearms, even after they retire.$^{67}$ In New York, peace officer status is conferred upon uniformed court officers of the unified court system, court clerks of the unified court system in the first and second departments, the marshal, deputy marshal, clerk or uniformed court officer of a district court, and marshals or deputy marshals of a city court. ${ }^{68}$ Only the marshals and deputy court marshals of a city court must obtain a license to carry a handgun. ${ }^{69}$ Judges of New York City's civil and criminal courts and justices of the supreme court in the first and second departments may obtain a special license to carry a handgun. ${ }^{70}$ Until recently, even court clerks and court reporters had authority to carry concealed firearms, ${ }^{71}$ apparently to protect the judges. ${ }^{72}$

64. Illinois corrections officers are not considered peace officers. See Arrington v. City of Chicago, 45 Ill. 2d 316, 318, 259 N.E.2d 22, 24 (1970). California guards are peace officers, but their powers are only "for the purpose of carrying out the primary function of their employment or as required under Sections 8597, 8598, and 8617 of the Government Code (states of emergency)." Cal. Penal Code $\S 830.5$ (West Supp. 1984). New York corrections officers are considered peace officers under N.Y. Crim. Proc. LAW § 2.10(25) (McKinney 1981).

65. But see Arrington v. City of Chicago, 45 Ill. 2d 316, 259 N.E.2d 22 (1970). The court in Arrington held that self-protection is an insufficient justification for giving prison guards the right 10 carry guns at all times: "Although they may feel that they need to carry weapons for self-protection. they are no different in this respect from many other public officials." Id. at 318, 259 N.E.2d at 24.

66. In both California State Emplovees' Ass'n v. Enomoto, 118 Cal. App. 3d 599. 173 Cal. Rpur. 517 (1981), and California State Employees' Ass'n v. Way, 135 Cal. App. 3d 1059, 185 Cal. Rptr. 747 (1982), parole agents claimed that handguns were needed to ensure their personal safety. Ser supha note 62 . The plaintiffs in Way relied on several incidents of parolees shooting at parole officers. 135 Cal. App. 3d at 1066, 185 Cal. Rptr. at 750.

67. See Cal. Penal Code $\S 830.1$ (West 1970); Cal. Penal Code $\$ 12027$ (West 1982).

68. N.Y. Crim. Proc. LaW $\S 2.10(21)$ (a) - (d) (1981).

69. N.Y. Crim. Proc. LaW \& 2.10(21)(d) (1981).

70. N.Y. Penal Law $\$ 400.00(2)$ (d) (McKinney Supp. 1983) (“A license for a pistol or revolver shall be issued to . . . have and carry concealed by a justice of the supreme court in the first or second judicial departments or by a judge of the New York city civil court or the New York city criminal court ....").

71. Court clerks are considered peace officers under N.Y. Crim. Proc. LAW $\$ 2.10(21)(b)$ (McKinney 1981); court reporters were given the same privilege in Association of Surrogates \&: Supreme Court Reporters v. Evans, 102 Misc. 2d 883, 424 N.Y.S.2d 818 (1979). The legislature eliminated the court reporters' right to carry handguns. Compare N.Y. Crim. Proc. L.III $\$ 2.10(21)$ (McKinney 1981) (and accompanying text) wilh N.Y. CrIM. Proc. L.Aw \$ $1.20(33)$ (d) - (g) (1977).

72. Although the court in Association of Surrogates \& Supreme Court Reporters v. Evans. 102 Misc. 2d 883, 424 N.Y.S.2d 818 (1979), considered the point to be "mere speculation." the 
No good justification for exempting these groups-and not scores of others-is apparent. Court clerks, court reporters, and judges have no special peacekeeping function ${ }^{73}$ or special handgun expertise; their handguns are as vulnerable to misuse or theft as those of other people. Other criminal justice system personnel, such as prosecutors, jurors, and witnesses, do not enjoy whatever security armed self-protection may afford, although they may be just as vulnerable. ${ }^{74}$

If special vulnerability to victimization justifies exemption from a handgun prohibition, there are many subgroups and countless individuals whose claims would be stronger than those of prison guards, probation and parole officers, and judges and court personnel. Similarly, if the crucial justificatory criterion is special reliability, there are numerous groups and countless individuals whose claim is as strong. As the police exception expands to embrace all sorts of public officials, more private citizens will doubt the equity of the prohibition. Moreover, a handgun prohibition which leaves large numbers of government employees armed will be anathema to those people who tend to distrust government and governmental elites.

\section{The Private Police}

The expansionist tendency of the peace officer exception becomes even more apparent when the status of private security personnel is examined. The private security sector has grown substantially since the early 1960's. There are approximately one million crime-related security workers in the United States, filling such diverse roles as private investigators, watchmen, and neighborhood and community patrols. ${ }^{75}$ They guard factories, utilities, banks, stadiums, department stores, shopping centers, office complexes,

respondents' brief argued that the law clerk was the judge's only source of protection within chambers or while in transit to the courtroom. Id. at $885-86,424$ N.Y.S.2d at 820 .

73. Association of Surrogates \& Supreme Court Reporters v. Evans, 102 Misc. 2d 883. 885. 424 N.Y.S.2d 818, 820 (1979). As the court in Ezans stated:

There is nothing in the job definitions or in the record to show that law clerks are involved with peacekeeping duties any more so than court reporters. There is some attempt in the affidavits annexed to the respondents' answer to attribute security or peacekeeping duties to law clerks Id. but it is not substantiated by the record.

74. Indeed, it is likely that witnesses are much more vulnerable

75. In their updated version of the 1971 Rand Corporation study of the private security industry, Kakalik and Wildhorn found that there were 1.1 million crime-related security workers in this country in the early 1970 's. Of these, 429,000 were privately employed and 113,000 were government-employed guards and watchmen. The number of private police and detectives remained constant through the 1960 's, while the number of guards and watchmen grew by one-third. J. Kakalik \& S. Wildhorn, The Private. Police: Security and Danger 17-18 (1977).

The Task Force on Private Security found that the average annual growth rate of security goods and services through the early 1970's was between $10 \%$ and $12 \%$ and that the total number of security employees emploved by American Society for Industrial Security (ASIS) members was 880,000 in 1975 . The task force also estimated that the number of ASIS security cmployees reached one million in 1976. Task Force on Private Security, Private Seciritr 35, 399-400 (1976) [hereinafter cited as TASK Force].

In 1975, studies found that private security personnel outnumbered local police in St. Louis. New Orleans, and Cleveland (Cuyahoga County). Id. at 35; D. Brennan. The OTHFr Police (1975) (Cuyahoga County study). 
retirement communities, apartment buildings, and scores of other facilities. Their very existence shows that federal, state, and local governments fail to meet society's demand for security services. ${ }^{76}$

A Rand Corporation study conducted in the mid-1970's found that approximately fifty percent of private security personnel carry a firearm while on duty. ${ }^{77}$ At the time, this amounted to approximately 200,000 people. Presumably, most guards carry their firearms to and from work as well. To determine whether a general handgun prohibition should exempt private security personnel, their role and status must be examined.

The San Francisco and Morton Grove handgun control laws carve out broad exceptions for security guards despite their lack of training and reliability. Why? In searching for an explanation, it is important to recognize private security's vital place in the law enforcement sector. ${ }^{78}$ By permitting and perhaps encouraging business organizations, groups, and individuals to purchase their own security services, the public police have been able to concentrate their resources elsewhere and local governments have avoided massive additional costs. Arguably, disarming the private half of the security sector would unhinge the internal security system developed over the past several decades and decrease the effectiveness of private security forces vis-avis the public police.

76. See J. Kakalik \& S. Wunhorn, supra note 75, at 90 " With few exceptions, guards perform work that the regular public police cannot perform because of legal constraints or because of resource limitations."). Kakalik and Wildhorn attribute the growth of the private security industry 10:

(1) the high level or rate of and increase in reported crime in all regions;

(2) increasing public awareness and fear of crime;

(3) the government's need for security for its space and defense activities during the past decade and, more recently, for security against violent demonstrations, bombings, and hijackings;

(4) a basic trend toward specialization of all services;

(5) withdrawal of some insurers from the market;

(6) insurers raising rates and/or requiring use of certain private security systems;

(7) insurcers offering premium discounts when certain private security measures are used;

(8) the growth of the electronics industry and advances in other scientific areas, which have sparked new branches of several protection companies, manufacturing greatly improved security devices, especially for intrusion detection: and

(9) a general increase in corporate and private income leading to more property to protect and, al the same time, more income to pay for protection. Id. all 19 .

77. An emplovec survey revealed that $48 \%$ of respondents carried firearms at least one-quarter

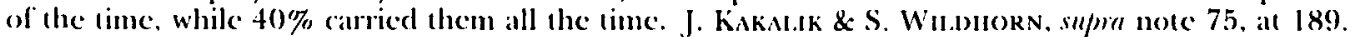
Similarly, a 1975 ASIS survey found that $45 \%$ of uniformed personncl are armed and that $30 \%$ of

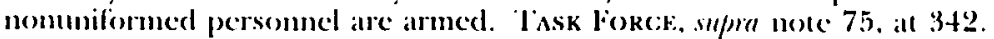

78. Although private sccurity personnel ofien have noncrime-related finctions, such as fire and equipment failure detection and comtrolling access to private property, all guards have certain

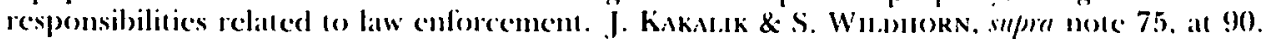

The major elistinction beeween public police and privale secorte personnel is that the public

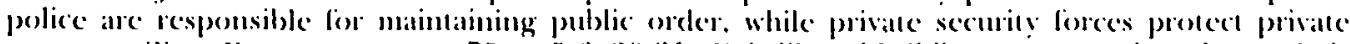
property. TAsk loker, supra note 75, at 5-(6. 20-21. Kakallik and Wildhom suggest that, due wo their diflering juriseliecions, public pelice linctions ane primarily investigative and anrest oriented, while

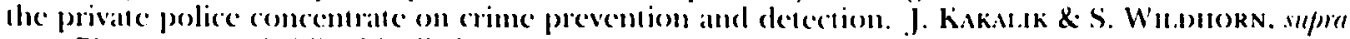

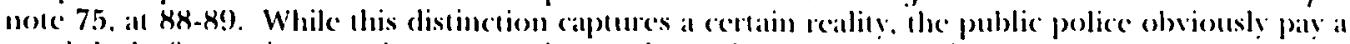
good deal of attention to crime prevention, order maintentance. and detertence. 
Just as it is a mistake to lump all police and police departments together, it would be a mistake to treat all private security guards and functions alike. A great deal of private security could very likely be (and often is) performed by unarmed guards. Other security functions have a more compelling need for armed protection. Banks, utilities, nuclear power plants, valuable art museums, and warehouses are highly vulnerable targets for professional and even amateur criminals, as well as terrorists. The appearance of less welldefended targets might increase these businesses' vulnerability to terrorism and violent crime. Thus, it makes sense to treat private security exceptions to handgun prohibition on a case-by-case basis. There does not seem to be a persuasive justification for exempting all or most security guards from a general gun prohibition. If all private security guards were permitted to be armed with handguns on the ground that it is necessary to protect important and vulnerable interests, a general disarmament policy would be in shambles, for there is no bright line between the private security guard and the private citizen concerned about the safety of his or her person, home, or business. ${ }^{79}$ Little, if anything, distinguishes a store owner possessing a handgun from a private security guard. In effect, the store owner serves as his own security guard.

The private citizen has no general arrest powers; neither does the security guard. ${ }^{80}$ The private citizen has no professional law enforcement expertise; neither does the private security guard who, on the same day, can be hired, given a handgun, and put on the job. ${ }^{81}$ If anything, the private security guard

79. A California poll on handgun ownership found that $64 \%$ of handgun owners in southern California and $41 \%$ in northern California owned handguns for self-protection. BUREAU OF Criminal Statistics, California Department of Justice, a Synopsis of a California Poll of Handing Ownership and Use 1 (1977), quoted in Hardy, Firearm Oumership and Regulation: Tackling an Old Problem will Renewed Iigor, 20 WM. \& MARY L. REv. 235, 243 n.35 (1978).

80. Unless the private security officer is deputized or has specific powers delineated by statute, his arrest powers are no greater than those of the private citizen. J. KAKALIK \& S. WILDHORN, supra note 75. at 213; TASK Force, supra note 75, at 391; Newby, Guard Regulation, in SEcurity MANACEMENT, Mav 1981 , at $30,36$.

81. A 1975 survey of state regulatory agencies and attorneys general found that only seven states required any firearms training for security employees. TASK Force, supra note 75, at 386-87. This record did not improve significantly over the next six years. In 1981, only a small minority of states required firearms training for armed security guards. Newby, supra note 80 , at 36 . "Very few stace statutes spell out training requirements, and those that do generally only designate certain subjects that must be covered." Id. Municipalities sometimes have more detailed training requirements.

The result of this indifference is that few guards are trained at all, and very few are trained adequatcly. An emplovee study conducted by the United Plant Guard Workers of America (UPGWA) indicated that although almost half of the guards surveyed were armed while working. less than onefifth had received any firearms training. A survey of plants with in-house security departments indicated that. while $29 \%$ of the guards are armed, only eight percent of the plants offer any firearms waining. J. KaKaLlK \& $\mathrm{S}$. WILDHORN, supra note 75 , at 122 . Thus, many new security guards are arned and immediately placed on assignment.

Iraining for other job-related duties is equally deficient: "The training a private guard receives before beginning work lasts typically no more than 8 to 12 hours, and many guards, including some who are armed, receive less than two hours of training." Sixty-six percent of the guards surveyed received no training. Id. at 121 . Even those who claim that private security forces are becoming increasingly professionalized point out the necessity of more training for more guards. The result of this lack of training is potentially disastrous. On a written questionnaire which tested guards' ability 
may be more likely than the average citizen to have a criminal record. Background security checks often take months to complete, if they are completed at all. ${ }^{82}$ The private security companies characteristically pay low wages and tolerate high turnover. ${ }^{83}$ It would be unrealistic to characterize the typical private security guard as well-trained or particularly "responsible." 44

Is there sound justification for a policy that entitles a large retail liquor store to protect itself with an armed Brinks guard or with one of its own specially designated armed security employees, but forbids the owner of the nearby "Ma and $\mathrm{Pa}$ " store to have his own gun? If the owner of the corner store were sufficiently affluent, he could hire a security guard to provide armed protection. ${ }^{85}$ If he is denied the prerogative of functioning as his own armed guard, he may perceive himself to be the victim of blatant class and wealth discrimination.

\section{E. Who Are the Private Police?}

If all private security personnel were exempted from a general firearms prohibition, some government agencies would be faced with defining who is a security guard. What would prevent anyone from calling himself or herself a private security guard in order to obtain exemption from the handgun prohibition? ${ }^{80}$ What prevents any group of people from starting a private security firm to protect their neighborhood, shopping center, or subway system?

to handle certain employment-related situations, $97 \%$ of those surveyed made at least one error that could have led to a lawsuit or to criminal charges. Id. at 179-81.

82. Adequate investigation of applicants for security jobs is hampered by:

(1) the amount of time available for the screening process, from the time of application to the lime the employee is scheduled to start work;

(2) the amount of funds an employer can economically allocate for the screening process: and

(3) the availability of the needed information.

TASK FORCE, supra note 75, at 71 . Fingerprint searches alone can take up to nine months itl some states. Id. at 72 . The conscientious employer may find it impossible to obtain accurate information on whether the new employee is fit for the job.

Many states attempt to regulate hiring practices. However, the flexibility of standards and the inability of state agencies to cnforce them hamper efforts to mandate adequate screening.

83. Commentators point to poor wages and benefits as the major reason for low-quality personnel. J. Kakilik \& S. Wildhorn, supra note 75, at 101: TASk Force, supra note 75. at 67-68. Indicative of the problems created by inadequate compensation is the high tumover rate at many security firms. Annual turnover rates in 1970 were estimated to range from less than $10 \%$ in some in-house agencies (where wages and benefits are usually better) to more than $200 \%$ at some contract agencics. J. KakALIK \& S. WIIDHORN, supra note 75, at 102 . A 1980 Califomia estimate placed turnover al over 300\%. San Francisco Examiner, Aug. 26, 1980. al 1. col. 2.

84. Cases of criminality by private security guards or former private security guards are common. For example, the "Mclonald's murderer" in San Isidro, California, during the summer of 1984 was a former private security guard. MaCi.tan's MaG., July 30, 1984, at 23, 23.

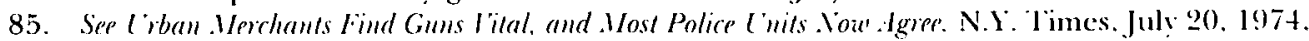
at 39 , col. 1 .

86. As of 1980, about threc-quarters of the states imposed licensing requircments on privale security agencies. Many municipalities in nonregulating states also impose requirements. To summarize: 
The private security sector is divided about equally between contract guards and in-house guards, ${ }^{87}$ although there are also a small number of private detectives and high-tech security specialists. Contract guards are hired, outfitted, and sometimes trained by companies selling security services to businesses, organizations, and individuals. In-house guards are designated security personnel working for an employer whose main business is something other than security. Generally, there is no regulation of in-house security operations and only limited regulation of contract security companies. ${ }^{8 x}$ Payment of a license fee and filing a security bond are usually sufficient to begin operating as a private security firm. There are few, if any, restrictions on the recruitment of individual security guards. ${ }^{89}$

(1) Thirty-three of the licensing states require a surety bond, which could range from $\$ 2,000$ to $\$ 300,000$;

(2) twelve states require examinations;

(3) most states require a minimum of two years' experience in public or private security;

(4) thirty-seven states require high moral character;

(5) sixteen states require that agency chiefs be United States citizens;

(6) all thirty-seven states in the survey (nonregulating states plus Ohio and Arkansas were

left out of this section of the survey) required that chiefs have no prior felony convictions;

(7) thirty of these require no criminal records;

(8) all require fingerprinting.

See Summary of State legislation Affecting Privale Security, Securitr Management, Apr. 1980, at 54, 54-59. Feven in licensing statcs, not all types of security agencies are subject to licensure. In fact, some states exclude in-house guards and guard patrol agencies from licensing. See J. Kakalik \& S. Wildhorn, sutpra note 75 , at 152 .

87. In-house police and detectives, guards, and watchmen totalled 225,000 in 1972; contract police and detectives, guards, and watchmen numbered 176,000, while an additional 28,000 were cmployed by armored car services and alarm services. J. KAKALIK \& S. WILDHORN, supra note 75, at 18.

88. State or local regulation of the private security industry consists of licensing of agencies and registration of cmployees. In-house security personnel are hardly ever subject to such requirements. Note, Reality and Illusiom: Defming Privale Security Law in Ohio. 13 U. Tor. L. Rev. 377, 384 (1982).

For examples of state law on in-house security operations, sec Cal.. Bus. \& Pror. Code \$ 7522(a) (West 1975) (in-housc guards who carry firearms must complete a training course, but security personnel who work for one employer and who do not carry weapons do not have to be registered): It.. ANN. STAT. ch. 111, \$2602 (Smith-Hurd 1978) (in-house employees are not subject to registration statutes, but in-house guards must complete a training course to carry a concealed firearm under ch. $38, \$ \$ 70-71,81)$. The Illinois statute only regulates those businesses and their employees doing business with the public; therefore, in-house operations are not affected. Ill. Op. Att'y (ien., 21 Dept. Rep. 495 (1979).

89. Most states require some form of registration or licensing for full-time employees, but only

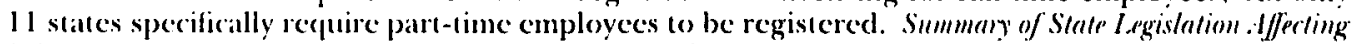
Privente Serurty, supra note 86, al 54-55. Since part-time employees account for up to $50 \%$ of the staff

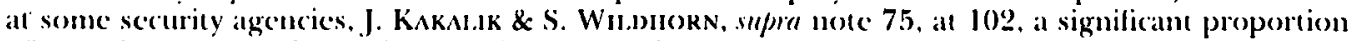
of security personnel remain outside the regulattory structure. even in those states that require registration or licensing.

Where employees must be registered or licensed, the reguirements are far firom demanding. ()ptimally. scrurrity cmployment requirements should sereen out those" who are dishonest. cotrup)t. laz, or emotionally or physically unstable." Thsk fores, smpm nesc 75. al 71. Howerer. he reguirements do little more than provide a check againse hiring convicted fetons. For cxample, (Ohio

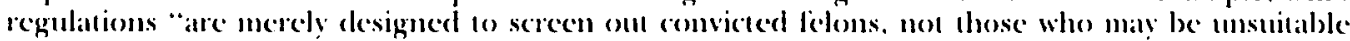

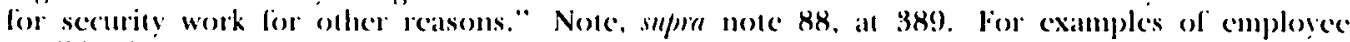
qualification slatules. sec 11... ANN. STAT, ch. 111 . \$ 2622 (Smith-Hurd l!)78) (an cmployec camot have been convicted of a lelony or other oflense involving monal turpitude within lo years of application and must be both a (I.S. citizen and al least 21 years of age): N.Y'. (Fr... Bus. Law $\$ 81$ (McKinney l968) (limpleyees must not have becu convicted of a felony or such misdemeanor's as firearms violation, pessession of burglar's cools, of mulawfill entry, allihough those who received 
At best, it is very difficult for a licensing agency, with limited staff, to distinguish between legitimate and illegitimate private security firms. ${ }^{90}$ If any person or persons could avoid the handgun prohibition by forming a security firm, there would be a gaping loophole in the handgun prohibition net. A nation serious about gun control would have to find a way to limit the use of handguns by private security guards. While it will not be possible or desirable to deny guns to guards protecting such highly vulnerable and publicly significant targets as nuclear power plants and banks, the presumption should be against licensing private security guards to carry handguns.

\section{F. The Citizenry}

What justification is there for exempting business persons from the prohibitory norm? Handgun prohibition would mean only that nonbusiness citizens are unable to possess weapons. Would this be a reasonable place to draw the line? Why should the protection of business property be a higher priority than the protection of residential and personal property?

Sometimes it is difficult to distinguish or disentangle the commercial and residential roles of private persons. Some people use their residences for business purposes. Would they, therefore, be privileged to possess handguns? The lower floors of some apartment buildings are utilized for commercial purposes. Would tenants on the upper floors be denied weapons permitted the business enterprises' employees on the lower floors? Conversely, would upper floor residents enjoy the privilege of possessing

executive pardons or a certification of good conduct from the parole board are excepted. Employees must be U.S. citizens or resident aliens, and may have to meet further criteria if required by the licensing authority.). Even statutes which disqualify only convicted felons may be invalid under the equal protection clause of the Constitution. Compare Schanuel v. Anderson, 546 F. Supp. 519 (S.D. Ill. 1982), affd, 708 F.2d 316 (7th Cir. 1983) (Illinois law prohibiting employment of convicted felon for 10 years following conviction held valid) with Smith v. Fussenich, 440 F. Supp. 1077 (D. Conn. 1977) (automatic disqualification of applicants with prior felony convictions held to violate the equal protection clause).

Even where administrators are permitted to disqualify employee-applicants for other reasons, they are often unable to do so. Enforcement of private security regulations is usually entrusted to agencies with little capacity for investigation. See J. Kakalik \& S. WILDHorn, supra note 75, at 152. Furthermore, because of the expense, even "well-meaning" firms cannot conduct thorough investigations. See supra note 82 and accompanying text.

The results of hiring inadequately screened personnel can be tragic. See, e.g.. One Big Security Risk Is the Security Guards, Some Companies Find, Wall Street J., Aug. 30, 1983, at 1, col. 6.

90. Poorly staffed regulatory agencies face enormous enforcement problems. As of 1975, very few states had more than 10 employees responsible for enforcing private security regulations. California, which is one of the best-staffed states, had 10 employees to investigate 1,633 license applicants and 95,000 registered employees. At best, only cursory attention can be paid to confirming background information, investigating licensees' wrongdoing, and detecting illegal. unlicensed operations.

Although the quality of enforcement against both agencies and individual employees is improving, see J. KAKALIK \& S. WILDHORN, supra note 75, at 151-67, regulatory bodies still face awesome obstacles. For example, Ohio's Licensing Division had made great strides. Abuses such as licensing convicted felons as agency heads and doctoring the scores of required examinations werc curtailed. In addition, several agencies were suspended for failure to register their employces. Nonetheless, the license revocation power has rarely been invoked and the Licensing Division has not succeeded in screening out all of the potentially unfit applicants. Note, supra note 88, at 388-90. 
firearms, the protection of the armed employees of the business enterprises on the lower floors, or both, while residents in the building next door are forbidden to own firearms?

Consider a retirement community which boasts a private security force whose duties include checking cars entering the compound through a single access road, conducting patrols, and maintaining surveillance of individual homes. Must such a community disarm its private security force? If not, is there justification for allowing this community's security force to remain armed while forbidding those who live in modest homes in nearby towns to possess guns?

Handgun control advocates no doubt will remain unconvinced. They can be expected to support any limitation on gun possession as a move away from a system of near universal handgun eligibility toward a system of general prohibition, even one replete with gaping exceptions. The usefulness of such regulation is doubtful, however. Prohibition with gaping exceptions would legitimize a great deal of handgun ownership and thus fail to create an environment conducive to massive voluntary surrender of firearms or to cooperation with the disarmament program. In addition, it would generate intense and dysfunctional conflict, litigation, and politicking as various groups and interests struggle to obtain their own exceptions or fit themselves within existing ones.

\section{IV}

\section{Conclusion: The Police and Private Security Exemptions RECONSIDERED}

Men and women desire to possess handguns for many reasons, including safety, security, and self-defense. ${ }^{91}$ Many have "learned," from the example set by police, peace officers, and the private security sector (reinforced by the media), that firearms are "necessary" for personal security. The personnel of such agencies may be so accustomed to their handguns that they find alternative weapons and protective devices unimaginable. This attitude may be a major stumbling block to formulating a coherent and successful firearms policy. If the police feel handguns are absolutely necessary, especially for self-defense, and if they refuse to accept the risks that might be entailed in disarmament or de-armament, all sorts of other groups and individuals will inevitably take the same position. Police leadership on the issue of gun

91. A 1975 national survey found that for 55 percent of all gun owners, self defense was at least one of the reasons they owned a gun.... In two national surveys conducted in 1978, 21 percent and 25 percent of all gun owners said self defense was the most important reason they owned a gun. Among the handgun owners, 45 percent owned their guns for this reason. A 1977 survey of Illinois residents indicated that among persons who owned only handguns, 57 percent owned them cxclusively for protection, while another 10 percent indicated protection was their main purpose. In a Florida survey, 54.5 percent of handgun owners said protection was their primary purpose for purchasing the gun. Similar results were obtained in a survey of California handgun owners.

Kleck \& Bordua, The Assumptions of Gum Control, in Firearms and Violence, supra note 29, at 31 (emphasis in original). 
control does not guarantee shrinkage of the arms pool, but without police leadership, further arms proliferation and escalation seems inevitable.

For law enforcement personnel who are not police officers, the right to carry handguns may symbolize status equivalence, societal respect, and professionalism. Private police perform functions fairly similar to those of police. They present a serious dilemma for would-be handgun prohibitionists. It would be extremely difficult for society to have it both ways-relying on private police to shoulder a large share of the law enforcement load, but treating private security personnel as mere private citizens when it comes to firearms policy. If policymakers acknowledge the value of handguns for self-defense and crime prevention by allowing private security personnel to carry handguns, however, the moral coherence of handgun prohibition is seriously, perhaps fatally, weakened. Large numbers of private citizens remain unshakably convinced that they need handguns in their stores and in their homes to deter or thwart criminal predators.

The San Francisco and Morton Grove ordinances demonstrate that even "radical" gun control legislation is far from a total prohibition. Just to draft ordinances of this kind forces lawmakers to judge the relative merits of various groups' and individuals' asserted needs to own handguns. These judgments in turn require a coherent firearms philosophy which, unfortunately, does not exist. The risk is a system of stringent gun control riddled with so many categorical and ad hoc exceptions that it legitimates almost as many guns as the current policy of universal access, except for particular untrustworthy groups. A prohibition like that is not worth much; it would lack the legitimacy necessary to convince gun owners to disarm and potential gun buyers to change their minds. ${ }^{92}$

A handgun prohibition must be symbolically right as well as politically expedient. A prohibition that accommodates the concerns and influences of all kinds of powerful interests will not be worth the paper on which it is printed. More than legislation is needed to reverse the internal arms race. A disarmament climate must be created, and that can best (perhaps only) be accomplished through police leadership and example. The best strategy toward handgun disarmament may not be to chip away at peripheral owners, but to change the attitudes, values, and practices of the core ownership group-the police, other law enforcement personnel, and private security forces.

There is no "solution" to the problem of gun violence in the United States. Even if disarming and de-arming the police could help to change public perceptions about the necessity of owning and carrying firearms, thereby shrinking the overall civilian stockpile of weapons, only some of the

92. Paul Aaron and David Husto point out that national prohibition was not a complete ban on the manufacture, sale, and purchase of alcoholic beverages. There were many exceptions that made enforcement difficult and evasion much easier. Aaron \& Husto, Temperance and Prohibition in .tmerica: A Historical Oventiew, in Al.cohol and Public Policy: Beyond the Shadow of Prohibition 127 (M. Moore \& D. Gerstein eds. 1981). 
gun prohibitionists' goals would be fulfilled. With fewer firearms in civilian hands there might be fewer gun accidents, suicides, and fatal "crimes of passion," although even these effects are by no means assured.

The cost might be to make the police and private citizenry more vulnerable to violent criminals. It is implausible, at least in the short run, that changing the gun environment would convince young street criminals or hardened professional criminals to give up their weapons. Indeed, they might become more brazen. But perhaps here, too, police commitment to minimal gun use would have positive social and political ramifications. The use of a gun in committing a crime might come to be seen as an extraordinarily serious matter justifying an extraordinarily long prison term. ${ }^{93}$ Perhaps over time there would be fewer gun crimes, but only perhaps.

One comes back again and again to the dilemma of gun control: how to reduce the negative consequences of firearms without placing undue risks on innocent people. I cannot help but think that we would all be more secure, and that we would have a better society, if the number of firearms could be reduced. I am not impressed with the argument that greater security can be obtained by the opposite policy, permitting and even encouraging more and more civilian firearm ownership and use (of ever more powerful weapons), just as I am not convinced that the international arms race can produce greater security among the world's superpowers. But, to be sure, gun control, like a nuclear freeze, is a serious risk. We would not be better off domestically or internationally if only "our side" disarms. Gun control would, in my judgment, only be desirable if it led over time to fewer armed crimes. Perhaps this argues for a long-term effort at suppressing violent crime on the one hand and assuring the personal safety and security of the general population on the other hand. Providing the law-abiding citizenry with some self-defense alternatives to guns should be a top priority.

The best that can be hoped for is slowly to change societal attitudes about the necessity and usefulness of guns. This change cannot be accomplished without strong leadership from the police and the elite sectors of society. As long as the police, who are so visible, operate under the assumption that firearms are essential for their safety and security, there is no prospect for substantial reduction in civilian armaments. ${ }^{94}$ The rest of the population will take its cue from the police and the private security sector, reinforcing its belief that firearms are essential to personal and household security.

93. See supra note 31.

94. Consider the following:

The Los Angeles Police Department is testing several types of semiautomatic pistols with more than double the firepower of the .38-caliber revolvers now in use at the department. The department is becoming "more and more outgunned every day" in comparison to heavily armed criminals, a spolesman said; thus it is testing possible replacements for the standard revolver currently issued to officers.

Crim. Just. Newsletter, Jan. 16, 1986, at 7, col. 2. 